\title{
Harmful Interactions of Non-Essential Heavy Metals with Cells of the Innate Immune System
}

\section{Theron $\mathrm{AJ}^{1,2 *}$, Tintinger $\mathbf{G R}^{1}$ and Anderson $\mathbf{R}^{1,2}$}

${ }^{1}$ Medical Research Council Unit for Inflammation and Immunity, Department of Immunology, Faculty of Health Sciences, University of Pretoria, South Africa ${ }^{2}$ Tshwane Academic Division of the National Health Laboratory Service, Pretoria, South Africa

\begin{abstract}
In trace amounts, some heavy metals are essential for optimum health, while exposure to others, which are non-essential, presents the potential hazard of acute or chronic organ toxicity. Cadmium, mercury, lead, vanadium, platinum and palladium are commonly encountered, non-essential heavy metals which mediate their toxic activities by various mechanisms. All have the potential to interact with extracellular and intracellular protein sulfhydryls, rendering them not only potentially allergenic, but also predisposing to oxidative stress, while displacement of essential elements from their protein carriers may result in deficiency disorders. In addition, several of these metals, especially cadmium, palladium, platinum, and vanadium interact pro-oxidatively with the phagocytic cells of the innate immune system, potentiating the reactivity and toxicity of phagocyte-derived reactive oxygen species. This review is focused on the pro-oxidative/pro-inflammatory interactions of non-essential heavy metals with the cells of the innate immune system, a somewhat under-appreciated mechanism of metal induced toxicity.
\end{abstract}

Keywords: Cadmium; Lead; Macrophages; Mercury; Neutrophils; Palladium; Reactive oxygen species; Vanadium

\section{Introduction}

Heavy metals comprise a heterogeneous group of elements, some of which are essential cofactors for various enzymes, while others are non-essential. The former group includes the trace elements cobalt, copper, iron, manganese, molybdenum, selenium and zinc. Because excessive concentrations of the free metals pose potential health risks, their circulating and tissue concentrations are tightly regulated through interactions with binding proteins. The latter group includes metals such as arsenic, cadmium, lead, mercury, plutonium, tungsten and vanadium [1]. These non-essential metals are potent toxins and gain access to organisms by virtue of physico-chemical properties, such as ionic charge, shared with their essential counterparts [2]. They may enter the body through food, water, air, or by absorption through the skin following inadvertent occupational exposure in the agricultural, manufacturing/industrial settings, or through environmental exposure. The manufacturing/industrial setting is the most significant source of exposure in adults [3].

Notwithstanding their direct cytotoxic effects on eukaryotic cells at high concentrations, interactions of non-essential heavy metals at lower non-cytotoxic levels with cells of the innate immune system, which abound in the airways, skin, gastrointestinal tract, liver, spleen, kidneys and circulatory system, may initiate harmful inflammatory responses with accompanying organ dysfunction and disease. These potentially harmful pro-inflammatory interactions of non-essential heavy metals (toxicants), specifically cadmium, lead, mercury, platinum, palladium and vanadium, with the cells of the innate immune system, and their adverse effects on health, are the topic of this review, which also includes cigarette smoking as a cause of exposure to heavy metals [4]. Of necessity, a consideration of the pro-inflammatory activities of these metals is preceded by a brief consideration of innate cellular defence mechanisms.

\section{Innate Immunity}

Innate immunity encompasses effector cells and proteins that serve as a first line of defence against infectious agents, restraining or, in some cases eliminating, microbial or viral pathogens while the host develops an adaptive, antigen-specific immune response [5]. Key cellular components of innate immunity include phagocytes such as neutrophils and monocytes/macrophages, as well as dendritic cells, mast cells, eosinophils, basophils and natural killer cells. Innate defenses also encompass physical barriers such as the epithelial and endothelial cell linings. Although not strictly classified as being cellular elements of the innate immune system, epithelial cells and endothelial cells are key orchestrators of both innate and adaptive immune responses.

Phagocytes accomplish their task at sites of infection by phagocytosing and killing bacteria and fungi, utilizing an arsenal of toxic molecules such as proteolytic enzymes and reactive oxygen species (ROS) (Table 1), as well as bacteriocidal proteins, which synergize/harmonize to eliminate these pathogens [6-7]. Although effective, these antimicrobial systems are indiscriminate and may cause significant inflammation-mediated damage to bystander host tissues if inappropriately and/or excessively activated. Excessive production of ROS may result in damage to lipids, proteins, or DNA, compromising cellular function, with resultant cytotoxicity. Because of this, chronic oxidative stress has been implicated in a number of human degenerative diseases, including cancer, cardiovascular disease, chronic obstructive pulmonary disease, atherosclerosis, neurodegenerative diseases (Alzheimer's disease and Parkinson's disease), rheumatoid arthritis, renal diseases, and ageing [8-9].

Cells of the innate immune system such as neutrophils and macrophages are also able to synthesize pro- and anti-inflammatory

*Corresponding author: Theron AJ, Department of Immunology, PO Box 2034, Pretoria-0001, South Africa, Tel: +27-12-319-2623; Fax: +27-12-323-0732; E-mail: atheron@medic.up.ac.za

Received February 27, 2012; Accepted April 13, 2012; Published April 16, 2012

Citation: Theron AJ, Tintinger GR, Anderson R (2012) Harmful Interactions of NonEssential Heavy Metals with Cells of the Innate Immune System. J Clinic Toxicol S3:005. doi:10.4172/2161-0495.S3-005

Copyright: (c) 2012 Theron AJ, et al. This is an open-access article distributed under the terms of the Creative Commons Attribution License, which permits unrestricted use, distribution, and reproduction in any medium, provided the original author and source are credited. 
Citation: Theron AJ, Tintinger GR, Anderson R (2012) Harmful Interactions of Non-Essential Heavy Metals with Cells of the Innate Immune System. J Clinic Toxicol S3:005. doi:10.4172/2161-0495.S3-005

Page 2 of 10

cytokines, growth factors and chemokines that mediate a wide range of physiological responses, primarily in host defence. In addition to their role in immunity and inflammation, however, overproduction of pro-inflammatory cytokines such as interleukin- $1 \beta$ (IL-1 $\beta$ ), tumour necrosis factor (TNF) and interleukin-6 (IL-6), as well as chemokines such as interleukin-8 (IL-8, CXCL8), monocyte chemotactic protein-1 (MCP-1, CCL2) and macrophage inflammatory protein-1alpha (MIP$1 \propto$, CCL3) can trigger a variety of pathophysiological conditions [10].

The major mediators of inflammation released by cells of the innate immune system and their potential pathological effects are shown in Table 2.

\section{Cadmium}

Cadmium $(\mathrm{Cd})$ is released into the environment through various industrial and domestic activities. Foremost amongst these are the combustion of fossil fuels (coal, diesel, gasoline etc.), incineration of industrial waste (especially Cd-containing batteries and plastics), metal alloy production, electroplating, and manufacture of phosphate fertilizers [11]. Cd is also present in tobacco, with each cigarette containing 1-3 $\mu \mathrm{g}$ of the metal, predisposing both active and passive smokers to the toxic effects of Cd inhalation [11]. In welders, acute exposure to Cd may lead to pneumonitis, pulmonary edema and death, with a Parkinsonism-like neurological disorder being a late effect of acute toxicity [1].

Notwithstanding predisposition to pulmonary disease, renal dysfunction is the most common adverse health effect of chronic exposure to Cd [12].

Cadmium toxicity may also result in osteoporosis by inducing renal tubular dysfunction with consequent increased urinary losses of calcium and phosphate as well as a direct effect on bone osteoblast and osteoclast activity [13-14]. Heavy metal toxicity in the setting of iron-deficiency anaemia may significantly increase the risk of infection as both iron-deficiency [15] and Cd-toxicity impair host responses to infection. Cadmium and zinc compete for carrier molecule binding sites on cell membranes and high Cd concentrations antagonize Zinc absorption and uptake by cells. Therefore, Cd toxicity may predispose affected individuals to zinc deficiency which can disrupt normal cellular and immunological functions [16-18].

In addition to direct cytotoxic effects of $\mathrm{Cd}$ at high concentrations on various cell types, including mononuclear cells and macrophages [19-20], a considerable body of evidence exists which implicates harmful

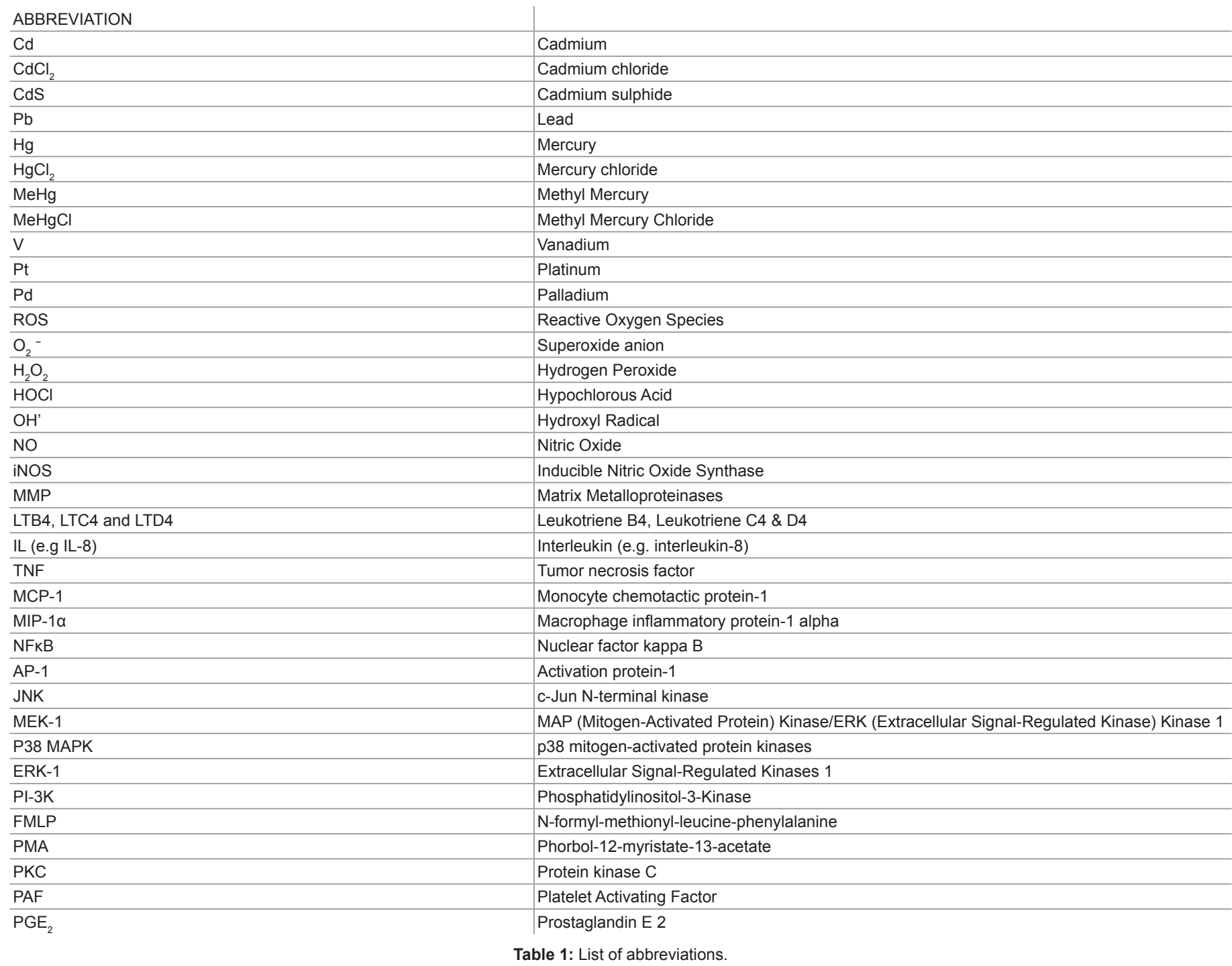




\section{Mediato}

Reactive oxidant species:

$\mathrm{O} 2-, \mathrm{H} 2 \mathrm{O} 2, \mathrm{HOCl}, \mathrm{OH}^{\prime}$

Nitric Oxide Synthase-derived Nitrogen Intermediates \& Peroxynitrite

Proteases e.g. serine proteases in the azurophilic granules: Cathepsin G, elastase, proteinase 3

Matrix metalloproteinases e.g. MMP-8 \& MMP-9

Lipid mediators: $\mathrm{LTB}_{4}, \mathrm{LTC}_{4}, \mathrm{LTD}$, Platelet Activating Factor (PAF), PGE

Cytokines: Pro-inflammatory cytokines e.g. IL-1, IL-6, TNF, IL-12, \& antiinflammatory cytokines, IL-1 receptor antagonist (IL-1Ra), IL-10

Chemokines: IL-8, Macrophage Inflammatory Protein(MIP)-1 $\alpha$ \& $\beta$, monocyte chemotactic protein-1 (MCP-1)

\section{Consequences of Overproduction}

Damage cellular lipids, proteins and DNA. Implicated in cancer, cardiovascular disease, atherosclerosis, neurodegenerative diseases and others [9].

Peroxynitrite implicated in cardio-vascular disease, neurodegeneration, diabetes etc [123].

Degrades matrix proteins such as elastin; implicated in emphysema, chronic bronchitis and cystic fibrosis [124]

Cause matrix breakdown in COPD, ARDS, sarcoidosis, and tuberculosis etc [125]

Overproduction of $\mathrm{LTB}_{4}$ associated with leukocyte recruitment is involved in the pathogenesis of inflammatory diseases such as bronchial asthma, rheumatoid arthritis, atherosclerosis, and inflammatory bowel disease [126]. LTC , LTD $_{4}$ play a role in asthma [127].

Overproduction of proinflammatory cytokines such as TNF may be involved in septic shock, autoimmunity \& inflammatory diseases [128].

Overproduction of chemokines such as IL-8 may be involved in inflammatory conditions, e.g. COPD, ARDS [129-130].

Abbreviations: LT: Leukotriene; PGE2: Prostaglandin E2; COPD: Chronic Obstructive Pulmonary Disease; ARDS: Acute Respiratory Distress Syndrome

Table 2: Mediators of inflammation released by cells of the innate immune system and their potential pathological effects.

pro-oxidative, pro-inflammatory interactions of Cd with neutrophils and macrophages in the adverse health effects of environmental and/ or industrial exposure to this metal. With respect to pro-oxidative activity, Freitas et al. (2010) reported that exposure of isolated human neutrophils to $\mathrm{CdCl}_{2}$ caused increases in the production of ROS, specifically $\mathrm{O}_{2}-\mathrm{H}_{2} \mathrm{O}_{2}$, and $\mathrm{HOCl}$, both spontaneously and following activation of the cells with the phorbol ester, phorbol myristate acetate (PMA) [21]. The latter is a direct activator of protein kinase C (PKC), which in turn activates the superoxide-generating system of phagocytes, NADPH oxidase [21]. These findings were confirmed by others and were extended to include murine macrophages and macrophage cell lines in which exposure of these cells to $\mathrm{Cd}(10 \mu \mathrm{M})$ also resulted in increased production of nitric oxide (NO), an activity which was associated with both increased activity and synthesis of inducible NO synthase (iNOS) [22-24]. Although the exact molecular mechanisms which underpin the pro-oxidative interactions of $\mathrm{Cd}$ with neutrophils and macrophages remain to be conclusively established, it is noteworthy that exposure of murine macrophages to $\mathrm{Cd}$ at concentrations of $20-500 \mu \mathrm{M}$ was found to increase cytosolic $\mathrm{Ca}^{2+}$ concentrations [25]. $\mathrm{Ca}^{2+}$ is a well-recognized second messenger, and increases in the cytosolic concentrations of this cation precede and are a prerequisite for receptor-mediated activation of NADPH oxidase [26].

Other mechanisms of Cd -mediated pro-oxidative activity include: i) inhibition of superoxide dismutase [27]; ii) bonding to sulfhydryl groups, depleting glutathione and protein sulfhydryls, thereby compromising intracellular anti-oxidative defences [28]; iii) activation of 5-lipoxygenase activity, leading to production of the neutrophil/ monocyte chemoattractant, leukotriene $\mathrm{B}_{4}$ ( $\left.\mathrm{LTB}_{4}\right)$, which also sensitizes these cells for increased activity of NADPH oxidase [29]; and iv) oxidative activation of redox-sensitive transcription factors such as nuclear factor kappa B (NFkB) and activator protein 1 (AP-1), which, in turn, activate the expression of genes encoding pro-inflammatory proteins, including iNOS [14,30-32].

The harmful pro-oxidative, pro-inflammatory activities of Cd have also been demonstrated in animal models of experimental pulmonary inflammation. Kataranovski et al. reported that intraperitoneal administration of $\mathrm{CdCl}_{2}(0.5-2 \mathrm{mg} / \mathrm{kg}$ body mass $)$ resulted in a dose-related elevation in the number of circulating neutrophils, as well as those present in lung tissue, which was associated with increased: i) adhesive and pro-oxidative activities of these cells; and ii) circulating levels of the pro-inflammatory cytokines TNF and IL-6, the latter being significantly correlated with the numbers of blood and pulmonary neutrophils [33]. In addition, Kirschvink et al. [34] reported that repeated ( $\mathrm{x} 3$ weekly for 3-5 weeks) $\mathrm{CdCl}_{2}(0.1 \%)$ nebulizations resulted in pulmonary inflammation in mice which was characterized by increased influx of neutrophils and macrophages in the setting of elevated levels of the matrix metalloproteinases- 2 and -9 . Histomorphometric analysis of the lung revealed changes compatible with emphysema, which correlated with the activities of the MMPs.

It is probable that Cd-mediated pulmonary inflammation and damage results from the pro-oxidative interactions of the metal with alveolar macrophages and other resident cells of the innate immune system, resulting in oxidative activation of NFkB and AP-1, leading to synthesis of IL-6, IL-8, and TNF [30,35-36]. In this respect it is also noteworthy that exposure of a murine macrophage cell line to $\mathrm{Cd}$ has been reported to activate a $\mathrm{Ca}^{2+}$-ROS-JNK-caspase-3 intracellular signalling pathway which promotes phosphorylation/ dephosphorylation of JNK and p38 MAPkinase, modulating cellular mitochondrial activity and proliferation, leading to apoptosis and necrosis [25]. The study by Kirschvink et al. [34] mentioned above is clearly compatible with a pathogenetic link between inhalation of $\mathrm{Cd}$ in cigarette smoke, chronic pulmonary inflammation, and development of emphysema. This contention is supported by the observation that relative to non-smokers, concentrations of Cd (and strontium) are elevated in the blood of cigarette smokers [37]. Furthermore, in a study to which 16024 adult humans were recruited, an increasing trend in urinary $\mathrm{Cd}^{2+}$ levels from never, through former, to current smokers was observed, which was negatively correlated with forced expiratory volume in 1 second $\left(\mathrm{FEV}_{1}\right)$ and the ratio of $\mathrm{FEV}_{1}$ to forced vital capacity (FVC), both indicative of airflow obstruction [38].

The pro-oxidative and pro-inflammatory effects of $\mathrm{Cd}$ on neutrophils and macrophages are depicted in Figure 1.

\section{Lead}

According to $\mathrm{Hu}$ [39], the worldwide production of lead $(\mathrm{Pb})$ is approximately 5.4 million tons and continues to rise. The major use of lead is in pb batteries, accounting for $78 \%$ of reported global consumption in 2003 [40]. This metal is also used in the production of pigments, glazes, solder, plastics, cable sheathing, ammunition, weights, fuel additives, and a variety of other products [39]. The predominant source of worldwide dispersion of $\mathrm{pb}$ into the environment for the past 50 years has been the use of $\mathrm{pb}$ organic compounds as anti-knock additives in motor vehicle fuels [39]. Emissions from this source have, however, declined with the phasing out of leaded petrol worldwide. 


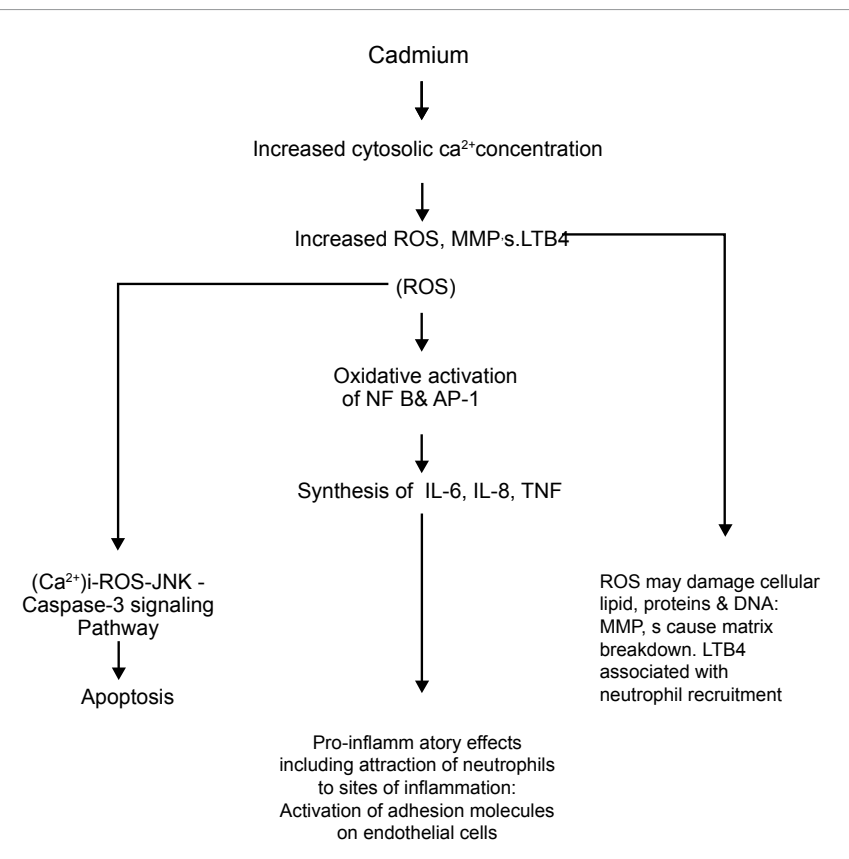

Figure 1: The pro-oxidative and pro-inflammatory effects of $\mathrm{Cd}$ on neutrophils and macrophages.

Lead is also present in tobacco, and Zielhuis et al. [41] demonstrated that blood lead levels in male and female students increased with the number of cigarettes smoked per day, although other sources of $\mathrm{Pb}$ such as exhaust fumes and food may also play a role. Lead levels among adults with high second-hand smoke exposure were found to be similar to those of smokers [42].

Depending on the dose, $\mathrm{pb}$ exposure can cause a wide spectrum of health problems, including neurological, cardiovascular, renal, gastrointestinal, haematological and reproductive disorders. $\mathrm{pb}$ accumulates in bone, which may serve as a reservoir for exposure in later life [40]. Children are particularly susceptible to lead intoxication, while at lower blood lead concentrations various neurological and behavioural problems may occur, ranging from a raised hearing threshold to a reduction in intelligence quotient (IQ) [43].

With respect to interactions with cells of the innate immune system, pb has been reported to negatively affect the functions of both neutrophils and macrophages. In the case of neutrophils, chemotaxis, the generation of ROS, and the killing of Candida albicans were found to be decreased in workers occupationally exposed to $\mathrm{Pb}$, even in those with blood levels below the currently acceptable biological lower limit [44-48]. On the basis of these observations, Quieroz et al. [46] suggested that immune dysfunction may be a sensitive indicator of exposure to $\mathrm{Pb}$. More recently, Di Lorenzo et al. (2006) reported an association between $\mathrm{Pb}$ exposure and the numbers of circulating neutrophils, with the strongest association being observed in occupationally-exposed workers who smoked [49]. This latter observation is not surprising given the well-recognized association of smoking with: i) neutrophilia [50]; and ii) increased levels of $\mathrm{Pb}$ in the blood of smokers as described above. Although the authors speculate that increased numbers of circulating neutrophils may represent a mechanism to compensate for $\mathrm{Pb}$-mediated immune dysfunction, they concede that it is more likely to reflect a neuroendocrine response to toxicity/stress. In this setting, increased production of endogenous glucocorticoids and catecholamines may contribute to both neutrophilia and neutrophil dysfunction possibly by interfering with the adhesion of these cells to vascular endothelium [49].

In the case of macrophages, $\mathrm{Pb}$, at non-cytotoxic concentrations of $0.1-10 \mu \mathrm{g} / \mathrm{ml}$, has been reported to inhibit the production of NO by cytokine-induced cell lines by interfering with induction of iNOS at the level of gene transcription [51,52]. Moreover, exposure to $\mathrm{Pb}$, at a concentration of $1300 \mathrm{ppm}$, was found to inhibit the adherence of murine peritoneal macrophages to plastic tissue culture dishes, which may underpin the inhibitory effects of the metal on the migratory responsiveness of these cells $[53,54]$. These effects of $\mathrm{Pb}$ on the induction of iNOS and spreading of macrophages are opposite to the effects on cytokine production. Flohé et al. [55] observed that exposure of murine bone marrow-derived macrophages to $\mathrm{Pb}(0.2$ $20 \mu \mathrm{M})$, prior to activation with bacterial lipopolysaccharide, resulted in augmentation of production of TNF, IL- 6 and IL-12, as well as prostaglandin $\mathrm{E}_{2}$, while production of anti-inflammatory IL-10 was decreased. More recently, Valentino et al. [56], in a study designed to measure the circulating levels of pro- and anti-inflammatory cytokines in workers exposed to very low levels of $\mathrm{Pb}$, found significant increases in the plasma concentrations of TNF and IL-10 relative to those of nonexposed control subjects. They reasoned that the $\mathrm{Pb}$-mediated increase in IL-10 was a biological, anti-inflammatory strategy to counteract the increase in the production of pro-inflammatory TNF [56].

Several mechanisms, including pro-oxidative properties and antagonism of the second messenger function of $\mathrm{Ca}^{2+}$ have been proposed to explain the modulatory effects of $\mathrm{Pb}$ on the function of cells of the innate immune system. With respect to pro-oxidative activity, the chemical properties of $\mathrm{Pb}$ favour interactions with diverse bio-ligands, particularly protein sulfhydryls [57]. Increases in $\mathrm{Pb}$-binding proteins, as well as in glutathione (GSH), occur soon after metal exposure and are believed to protect against $\mathrm{Pb}$ toxicity [57]. However, by depleting glutathione and protein sulfhydryls, $\mathrm{Pb}$ can compromise host antioxidant defences, creating an intracellular environment conducive to the oxidative activation of transcription factors such as NFkB, while promoting oxidant-mediated inhibition of the protective functions of neutrophils and macrophages.

However, the prevailing theory of $\mathrm{Pb}$-mediated modulation of the functions of neutrophils and macrophages is that the metal may affect intracellular $\mathrm{Ca}^{2+}$ homeostasis, either by mimicking $\mathrm{Ca}^{2+}$ action and/ or antagonizing $\mathrm{Ca}^{2+}$-dependent cellular functions. Given the critical second messenger role of $\mathrm{Ca}^{2+}$, exposure to $\mathrm{Pb}$ may affect several intracellular signalling pathways, including those involving activation of protein kinase $\mathrm{C}$ possibly underpinning interference with neutrophil and macrophage functions as described above [58].

\section{Mercury}

Elemental mercury $(\mathrm{Hg})$ is liquid at room temperature, and in this form is less toxic than inorganic or organic bound Hg. Methylmercury $(\mathrm{MeHg})$, the most predominant form of organic $\mathrm{Hg}$, is the form that most commonly poses a health risk, mainly through fish consumption [59]. Between 2700 and 6000 tons of elemental $\mathrm{Hg}$ are released into the biosphere annually through degassing from the earth's crust and oceans [60,61]. Occupational (chloralkali plants, production of lamps and batteries, gold mining, dentistry) and environmental (dental amalgams, food) exposures to $\mathrm{Hg}$ also occur frequently [62]. According to reports "a single dental amalgam filling with a surface area of only $0.4 \mathrm{~cm}^{2}$ is estimated to release as much as 15 micrograms of $\mathrm{Hg}$ per day primarily through mechanical wear and evaporation." It is also stated that "the average individual has eight amalgam fillings and could absorb up to 
120 micrograms of $\mathrm{Hg}$ per day from their amalgams" [63,64].

$\mathrm{Hg}$ has been found to cause various health problems, including neurological, renal, immunological, cardiac, motor, reproductive and even genetic disorders [65]. Pre- or post-natal exposure to high levels of $\mathrm{MeHg}$ causes mental retardation, cerebral palsy, seizures and ultimately death [66], while inorganic $\mathrm{Hg}$ is known to induce autoimmune disease in susceptible rodent strains. Additionally, in inbred strains of mice prone to autoimmune disease, $\mathrm{Hg}$ can accelerate and exacerbate disease manifestations [67]. Metals such as $\mathrm{Hg}$ may also contribute to the pathogenesis of autoimmune diseases by modulating mast cell activity [68].

$\mathrm{Hg}$ has been reported to affect the functions of the cells of the innate immune system, including neutrophils, moncytes/macrophages, natural killer cells and dendritic cells as well as epithelial cells. In the case of neutrophils, Jansson et al. [69] reported that exposure of these cells to low micromolar $(\leq 5 \mu \mathrm{M})$ concentrations of $\mathrm{HgCl}_{2}$ in vitro resulted in significant, albeit variable, increases in the production of superoxide activated by the chemoattractant, $\mathrm{N}$-formyl-L-methionylL-leucyl-L-phenylalanine, but not with other activators such as PMA or opsonized zymosan. At approximately the same concentrations, $\mathrm{HgCl}_{2}$ and $\mathrm{MeHgCl}$ were found to inhibit spontaneous apoptosis of human neutrophils in vitro [70], possibly by a mechanism related to induction of mild oxidative stress. At higher concentrations, however, the metal (in both studies) was found to become abruptly cytotoxic $[69,70]$.

In contrast to the aforementioned studies which addressed the effects of short-term exposure to $\mathrm{Hg}$ on neutrophil function and viability in vitro, prolonged exposure to the metal in the workplace was reported to be associated with impairment of neutrophil chemotaxis and generation of ROS [71]. These effects persisted following reductions in exposure due to improvements in factory hygiene practices, prompting the authors to propose that exposure to $\mathrm{Hg}$, even at levels considered to be "safe", may lead to impairment of neutrophil function.

With regard to monocytes/macrophages, electron microscopic analysis of cells exposed to $\mathrm{MeHg}$ clearly revealed uptake of the metal with deposition in lysozomes and dispersal in the cytoplasm and nuclei [72]. Functional analysis of macrophages exposed to $\mathrm{Hg}$ (1-5 $\mu \mathrm{M}$ ) demonstrated: i) impairment of their phagocytic and migratory activities, possibly as a consequence of increased production of ROS by metal-exposed cells [72,73]; ii) increased production of LTB $_{4}[74]$, possibly resulting from increased activity of p38 MAPK [75], but not $\mathrm{NF \kappa B}$, which was actually decreased [76]; and iii) decreased production of NO in the setting of increased synthesis of the cytokines IL-6 and TNF, which was associated with increased activity of p38 MAPK, but not NFkB [76].

The stimulatory effects of $\mathrm{Hg}$ on the production of IL- 6 and TNF by macrophages are essentially in agreement with the findings of an earlier study by Villanueva et al. [36]. These authors reported that exposure of human peripheral blood mononuclear leukocytes to $\mathrm{HgCl}_{2}$, as well as to $\mathrm{CdCl}_{2}$ as mentioned earlier, resulted in increased production of both IL-1 $\beta$ and TNF in the setting of decreased production of antiinflammatory IL-10 and IL-1 receptor antagonist. The cytokines interferon- $\gamma$, IL- 4 and IL-17 which typify activation of the Th1, Th2 and Th17 sub-populations of $\mathrm{CD} 4^{+} \mathrm{T}$ cells of the adaptive immune system respectively, were also increased following exposure of mononuclear leukocytes to $\mathrm{HgCl}_{2}$ [77].

In addition to its effects on neutrophils and monocytes/ macrophages, $\mathrm{Hg}$, as mentioned above, has been reported to modulate the functions of natural killer cells, and epithelial cells. In the case of the former, dietary intake of $\mathrm{MeHg}(3.9 \mu \mathrm{g} / \mathrm{gram}$ diet $)$ by mice and rats resulted in suppression (42-44\%) of the tumoricidal activity of blood and splenic natural killer cells, as well as proliferation of the T-cells and B-cells of the adaptive immune system $[78,79]$.

More recently, Migdal et al. [80] investigated the effects of thimerosal and other Hg-containing compounds on the spontaneous expression of surface markers of cell activation, as well as on the production of the pro-inflammatory cytokine TNF, and the chemokine IL-8 by human monocyte-derived dendritic cells in vitro. The authors observed that exposure of the cells to all of these compounds was associated with over-expression of CD86 and HLA-DR, both of which mediate T-cell activation, as well as increased production of TNF and IL-8. From a mechanistic perspective, these pro-inflammatory interactions of $\mathrm{Hg}$ with dendritic cells were associated with increased intracellular oxidative stress, presumably as a consequence of interaction of the metal with glutathione and protein sulfhydryls, and delayed, oxidant-mediated influx of extracellular $\mathrm{Ca}^{2+}[80,81]$. Both of these events (increased intracellular levels of ROS and associated $\mathrm{Ca}^{2+}$ influx) result in activation of transcription factors and expression of genes encoding pro-inflammatory proteins.

Epithelial cells are also prone to metal-mediated oxidative stress as described by Han et al. [82]. These authors reported that exposure of the bronchial epithelial cell line (BEAS-2B) to $\mathrm{Hg}$ or, as mentioned earlier to $\mathrm{Cd}$ in particular, at concentrations of $0-50 \mu \mathrm{M}$, resulted in dose-related oxidative stress due to increased intracellular generation of the ROS, superoxide, $\mathrm{H}_{2} \mathrm{O}_{2}$ and hydroxyl radical [82]. Oxidative stress resulted from metal-mediated depletion of intracellular sulfhydryls, resulting in cytotoxicity.

The pro-oxidative, pro-inflammatory and cytotoxic properties of $\mathrm{Hg}$ are clearly similar to those of $\mathrm{Cd}$ and $\mathrm{Pb}$, resulting from the interactions of the metal with, and depletion, of intracellular sulfhydryl groups [83]. Oxidative stress, in turn, leads to influx of $\mathrm{Ca}^{2+}$ and activation of p38 MAPK, resulting in production of pro-inflammatory cytokines by cells of the innate immune system [25]. Excessive and prolonged oxidative stress, however, results in oxidative inactivation of protective functions such as adherence, migration and phagocytosis in the case of neutrophils and monocytes/macrophages, and ultimately to cell death by apoptosis due to p38 MAPK-mediated activation of caspase 3 and oxidant-mediated necrosis [25].

\section{Vanadium}

Metallic vanadium (V) does not exist in nature; rather, $\mathrm{V}$ compounds exist in oxidation states ranging from -1 to +5 , the most common valences being $+3,+4$, and +5 , with quadrivalent salts being the most stable. Occupational exposure to $\mathrm{V}$ is common in the petrochemical, mining, steel, and utilities industries; fossil fuels and some ores contain significant amounts of this metal [84]. Inhalation is the most prevalent route of human exposure to insoluble pentavalent $\mathrm{V}$ oxides and soluble salts in urban/occupational settings. Workers exposed to V-bearing dusts or fumes display an increased incidence of several lung diseases (e.g., asthma, bronchitis, pneumonia) [85]. Exposure to $\mathrm{V}$ can also take place through the smoking of cigarettes. The concentration of $\mathrm{V}$ in cigarettes ranges between $0.49-5.33 \mathrm{mg} / \mathrm{g}$ (average: $1.11 \mathrm{mg} /$ cigarette). About $60 \%$ of the vanadium remains in the ash, $8.3 \%$ in the cigarette filter and $31.3 \%$ in the smoke $[4,86]$.

Like the other metals, $\mathrm{V}$ has been found to interact pro-oxidatively with cells of the innate immune system, including neutrophils, macrophages, basophils, as well as epithelial cells. In the case of neutrophils, Fickl et al. [87] reported that exposure of activated human 
neutrophils to $\mathrm{V}(25 \mu \mathrm{M})$ in the $+2,+3$ and +4 , but not the +5 , valence states promoted hydroxyl radical formation by these cells. This was achieved by a Fenton reaction via interaction of the metal with $\mathrm{H}_{2} \mathrm{O}_{2}$ generated by active neutrophils. This mechanism may, however, be of greater relevance to macrophages as these cells do not possess myeloperoxidase, negating competition between the metal and the enzyme for $\mathrm{H}_{2} \mathrm{O}_{2}$. At much higher concentrations $(50-1000 \mu \mathrm{M})$ than those used in the aforementioned study, Grabowski et al. [88] reported that exposure of rat alveolar macrophages to sodium metavanadate (+5 valence state) resulted in a generalized, dose-related (from 50 $\mu \mathrm{M})$ increase in the intracellular generation of ROS. Exposure of the cells to the metal resulted in the activation of NADPH oxidase, as well as tyrosine phosphorylation of cellular proteins [88]. The authors propose that a mechanism involving V-mediated generation of ROS in macrophages, and possibly other cell types such as epithelial cells, may result in oxidant-mediated activation of intracellular signalling cascades, leading to synthesis of pro-inflammatory cytokines/ chemokines, which, in turn, promote the airway inflammation which accompanies inhalation of the metal. This contention was confirmed in a murine model of experimental airway inflammation in which aspiration of $\mathrm{V}(+5)$ into the pulmonary airspace was accompanied by influx of neutrophils, which was associated with increased production of ROS (superoxide, hydroxyl radical, $\mathrm{H}_{2} \mathrm{O}_{2}$ ) by alveolar macrophages ex vivo [89], as well as increased expression of genes encoding neutrophil and monocyte chemoattractants $[84,90,91]$.

In addition to alveolar macrophages, airway epithelial cells are also involved in $\mathrm{V}$-mediated airways inflammation, again as a consequence of intracellular oxidative stress. In an earlier study, Jaspers et al. [92] reported that exposure of primary human bronchial epithelial cells to $\mathrm{V}$ $(+4,12-50 \mu \mathrm{M})$ resulted in increased transcription of the IL-8 gene, as well as synthesis of the protein as a consequence of activation of NFKB. These observations are in keeping with the study of Zhang et al. [93] in which it was reported that exposure of the human lung epithelial cell line, $\mathrm{A} 549$, to $\mathrm{V}(+5,100 \mu \mathrm{M})$ resulted in intracellular generation of ROS (superoxide, hydroxyl radical, $\mathrm{H}_{2} \mathrm{O}_{2}$ ).

In the case of human basophils, Kitani and co-workers reported that exposure of these cells, as well as rat mast cells and basophilic leukaemia cells to $\mathrm{V}$ in the +4 and +5 valence states in combination with $\mathrm{H}_{2} \mathrm{O}_{2}(1 \mathrm{mM})$, but not the individual agents, caused the release of histamine, which was associated with increased intracellular $\mathrm{Ca}^{2+}$ levels, extensive protein tyrosine phosphorylation, and morphological changes. The authors proposed that $\mathrm{V}$ in the presence of $\mathrm{H}_{2} \mathrm{O}_{2}$ may exacerbate allergic reactions [94].

With respect to cellular signalling and activation of transcription factors, $\mathrm{V}$ compounds have been found to activate many key effector proteins of the signalling pathways including AP-1, MEK-1, ERK-1, JNK-1, PI-3K and NF- $\kappa B[95,96]$.

\section{Platinum Group Metals: Platinum and Palladium}

Palladium, platinum, rhodium, ruthenium, iridium and osmium form a group of elements referred to as the platinum group metals (PGMs). The increasing use of platinum group metals in vehicle catalytic converters leads to the emission of PGMs into the environment, while several other applications (e.g. industrial, jewelry, anticancer drugs, etc.), can also result in exposure to these metals [97]. They are also potent allergens and sensitisers, and are associated with asthma, nausea, increased hair loss, increased spontaneous abortion, dermatitis and other health problems in humans [98].

Platinum (Pt) and palladium (Pd) have been reported to affect the functions of human neutrophils and ciliated respiratory epithelial cells. In the case of neutrophils, both metals, but not rhodium or osmium, were found to potentiate the reactivity, as opposed to the generation of neutrophil-derived oxidants [99]. The potential health risk of these prooxidative interactions of the metals with neutrophils was demonstrated in a study in which alpha-1-proteinase inhibitor, the major antagonist of neutrophil elastase, was exposed to activated neutrophils in the absence or presence of Pt or Pd. Exposure to neutrophils in the presence of the metals significantly increased the magnitude of oxidative inactivation of the elastase-inhibitory capacity of alpha-1-proteinase inhibitor. If operative in vivo, these pro-oxidative interactions of $\mathrm{Pd}$ and $\mathrm{Pt}$ with neutrophils in the airways may predispose to pulmonary dysfunction in occupationally- and possibly environmentally-exposed individuals [99].

This latter contention is supported by three additional studies. Firstly, platinum in the +2 and +4 oxidation states was found to increase ROS production by the BEAS-2B bronchial epithelial cell line [100]. Secondly, in a study designed to investigate the role of metals in sino-nasal inflammation in individuals environmentally exposed to dense motor vehicle traffic it was found that platinum levels in the nasal lavage correlated with neutrophilic inflammation, as well as epithelial shedding [101]. Thirdly, Feldman et al. [102] reported that exposure of nasal ciliated epithelium to platinic chloride resulted in slowing of ciliary beating and damage to the structural integrity of the cells. These effects were enhanced in the presence of neutrophils and partially attenuated by catalase, confirming the involvement of neutrophilderived ROS in platinum-mediated dysfunction of ciliated respiratory epithelium [102].

A summary of the macrophage- and neutrophil-derived inflammatory mediators which are increased following exposure to heavy metals is shown in Table 3.

\section{Heavy Metals and Predisposition to Infection}

Cigarette smoking, as mentioned earlier, is a well-documented cause of exposure to heavy metals such as $\mathrm{Cd}, \mathrm{Pb}$ and $\mathrm{V}$, and a recognised risk for development of respiratory bacterial infection including tuberculosis and severe pneumococcal disease [103-105]. Moreover, cigarette smoke exposure has also been reported to induce the formation of biofilm by various common respiratory and oral pathogens [106,107]. Encasement in biofilm, a self-generated extracellular polymer matrix, is a survival strategy utilised by bacteria to promote persistence by evasion of both host defences and antibiotics, and has been implicated in $60-80 \%$ of all microbial infections [108]. Although the exact components of cigarette smoke which promote biofilm formation have not been established, it is noteworthy that nickel, which like $\mathrm{Cd}, \mathrm{Pb}$ and $\mathrm{V}$ is also present in tobacco has been reported to promote biofilm formation by Escherichia coli in vitro $[109,110]$. Alternative sources of exposure to $\mathrm{Cd}, \mathrm{Pb}$ and $\mathrm{V}$ include industrial and environmental pollution, high risk occupations and contaminated food such as fish $[111,112]$.

As mentioned earlier, heavy metals such as $\mathrm{Pb}$ and $\mathrm{Hg}$ may predispose to infection by promoting oxidative inhibition of the protective functions of neutrophils and monocytes/macrophages. Exposure to Pd may also compromise innate host defences, albeit by 


\begin{tabular}{|c|c|c|}
\hline Mediator & Effect & References \\
\hline ROS & $\begin{array}{l}\text { - Increased generation in } \mathrm{CdCl}_{2} / \mathrm{CdS}(0.6 \mu \mathrm{M}-1 \mathrm{mM}) \text { treated neutrophils \& macrophages. } \\
\text { - } \\
\text { - } \\
\text { - } \mathrm{Pt} \& \mathrm{Pd}(0.025-25 \mu \mathrm{M}) \text { potentiate reactivity of neutrophil derived ROS. } \\
\text { Vanadium } 2+, 3+, 4+(25 \mu \mathrm{M}) \text { mediate hydroxyl radical production from FMLP-\& PMA- } \\
\text { activated neutrophils. } \\
\text { Increased generation by rat alveolar macrophages treated with sodium metavanadate } \\
(50-1000 \mu \mathrm{M}) \text {. }\end{array}$ & $\begin{array}{l}{[21-23]} \\
{[72]} \\
{[99]} \\
{[87]} \\
{[88]}\end{array}$ \\
\hline NO & $0.6-10 \mu \mathrm{M} \mathrm{CdCl}{ }_{2}$ cause increased NO production by macrophages. & [23-24] \\
\hline LTB4 & $\begin{array}{l}\text { - } \quad<30 \mu \mathrm{M} \mathrm{CdCl}_{2} \text { augments LTB4 secretion by rabbit alveolar macrophages. } \\
\text { - } \quad \text { Production increased in neutrophils from lead exposed workers. } \\
\text { Increased generation by rabbit alveolar macrophages exposed to } \mathrm{HgCl}_{2}\end{array}$ & $\begin{array}{l}{[29]} \\
{[45]} \\
{[74]}\end{array}$ \\
\hline Cytokines & $\begin{array}{l}\text { - Increased production(or expression of mRNA) of IL-1, TNF, IL-6 by PBMC exposed to } \\
\mathrm{CdCl}_{2} / \mathrm{CdSO} 4(1-10 \mu \mathrm{M}) \text {. } \\
\text { Increased production of TNF, IL-6, IL-12, PGE2 and decreased production of IL-10 by Pb } \\
\text { treated macrophages. } \\
\mathrm{HgCl}_{2}(200 \mathrm{~nm}-5 \mu \mathrm{M}) \text { increases the production of IL-1 } 1 \beta, \mathrm{TNF}, \mathrm{IL}-6, \mathrm{IL}-8 \text { and } \\
\text { downregulates production of IL-Ra \& IL-10. }\end{array}$ & $\begin{array}{l}{[30,36]} \\
{[55]} \\
{[36,77]}\end{array}$ \\
\hline
\end{tabular}

Abbreviations: $\mathrm{CdCl}_{2}$, cadmium chloride; CdS, cadmium sulphide; $\mathrm{MeHgCl}$, methyl mercury chloride; Pt, Platinum; Pd, palladium; FMLP, N-formyl-methionyl-leucinephenylalanine); PMA, phorbol-12-myristate-13-acetate

Table 3: Macrophage- and neurophil-derived inflammatory mediators which are increased following exposure to heavy metals.

an unusual mechanism involving the inactivation of the neutrophil/ monocyte chemoattractants, IL8 and the complement cleavage product, C5a. Brief exposure to the metal $(25 \mu \mathrm{M})$ resulted in either partial (IL8) or complete attenuation (C5a) of both the Ca2+-mobilizing and chemotactic activities of the chemoattractants for neutrophils [113].

\section{Heavy Metals and Respiratory Disease}

Exposure to numerous metals may injure the lung directly or via interaction with cells of the innate immune system. Metal-induced injury may involve the airways, alveoli or interstial tissues of the lung or predispose subjects to bronchial carcinomas. Airway diseases such as bronchitis and bronchiolitis may occur following exposure to metal fumes containing $\mathrm{Cd}$ or $\mathrm{Hg}$ [114]. Chronic cadmium exposure may cause emphysema by inhibiting the synthesis of plasma $\alpha_{1}$-antitrypsin which predisposes to oxidant-mediated tissue injury. Furthermore, exposure to cadmium fumes has been reported to accelerate the progression of emphysema [115]. Not withstanding instead of Non withstanding the mechanisms described above, metals such as platinum, may act as haptens inducing IgE synthesis which, in susceptible individuals may lead to occupational asthma [116].

Metal fume fever is an acute inflammatory response triggered by pulmonary macrophages following exposure to fumes containing metal oxides such as cadmium oxide. Welders are at increased risk and symtoms such as fever, malaise, myalgia, dyspnea and cough begin about $4-8$ hours after exposure. Bronchial lavage fluid contains high concentrations of tumour necrosis factor-alpha, interleukin- 6 and interleukin- 8 as well as neutrophils. The course of the illness is selflimiting over 48 hours [116].

A severe form of acute lung injury manifesting as pneumonitis or the acute respiratory distress syndrome (ARDS) known as acute metal fume toxicity may occur following heavy exposure to $\mathrm{Cd}[117,118]$ and $\mathrm{Hg}$ [114]. These metals are cytotoxic and alveolar damage results in acute lung injury which may progress to respiratory distress.

Mercury in its metallic form may reach the lungs via embolization from the venous system and has been reported in intravenous drug users and in some cases of attempted suicide [119]. An acute inflammatory reaction is elicited in the lung in the form of a foreign body giant cell reaction. Interstitial lung fibrosis may follow the inflammatory response [120].

The carcinogenic potential of metals such as Cd [121] and arsenic [122] may increase the risk of bronchus carcinoma. Smelter workers exposed to these agents were more likely to develop lung cancer. Concomitant exposure to tobacco smoke may accentuate the risk of a pulmonary malignancy.

\section{Conclusion}

To minimize the risk of inflammation-mediated tissue damage to bystander tissues, activation of the cells of the innate immune system should be efficient and transient. Occupational and environmental exposure to heavy metals, especially Cd, Pt and V is, however, an important cause of inappropriate activation of these cells, predisposing to oxidant-and protease-mediated tissue damage. Cigarette smoking is a major, albeit eminently avoidable risk, which results in simultaneous exposure to multiple heavy metal toxins and may be compounded both by occupation and proximity to combustion of fossil fuels in the environmental setting. In these latter settings, in which avoidance may be difficult, frequent monitoring and early recognition of symptoms of metal- associated toxicity is recommended, with consideration given to the implementation of anti-inflammatory/anti-oxidative therapy where necessary.

\section{References}

1. Johri N, Jacquillet G, Unwin R (2010) Heavy metal poisoning: the effects of cadmium on the kidney. Biometals 23: 783-792.

2. Duce JA, Bush Al (2010) Biological metals and Alzheimer's disease: Implications for therapeutics and diagnostics. Prog Neurobiol 92: 1-18.

3. Singh VP (2005) Metal toxicity and tolerance in plants and animals. Sarup \& Sons, New Delhi.

4. Bernhard D, Rossmann A, Wick G (2005) Metals in Cigarette Smoke. IUBMB Life 57: 805-809.

5. Stoll G, Kleinschnitz C, Nieswandt B (2010) Combating innate inflammation: a new paradigm for acute treatment of stroke. Ann N Y Acad Sci 1207: 149-154.

6. Smith JA (1994) Neutrophils, host defense, and inflammation: a double-edged sword. J Leukoc Biol 56: 672-686. 
Citation: Theron AJ, Tintinger GR, Anderson R (2012) Harmful Interactions of Non-Essential Heavy Metals with Cells of the Innate Immune System. J Clinic Toxicol S3:005. doi:10.4172/2161-0495.S3-005

7. Kobayashi SD, Voyich JM, Burlak C, Deleo FR (2005) Neutrophils in the innate immune response. Arch Immunol Ther Exp 53: 505-517.

8. Rodrigo R, Rivera G (2002) Renal damage mediated by oxidative stress: a hypothesis of protective effects of red wine. Free Radic Biol Med 33: 409-422.

9. Valko M, Leibfritz D, Moncol J, Cronin MT, Mazur M, et al (2007) Free radicals and antioxidants in normal physiological functions and human disease. Int $\mathrm{J}$ Biochem Cell Biol 39: 44-84.

10. Hatanaka E, Monteagudo PT, Marrocos MS, Campa A (2006) Neutrophils and monocytes as potentially important sources of proinflammatory cytokines in diabetes. Clin Exp Immunol 146: 443-447.

11. Rennolds J, Butler S, Maloney K, Boyaka PN, Davis IC, et al. (2010) Cadmium regulates the expression of the CFTR chloride channel in human airway epithelial cells. Toxicol Sci 116: 349-358

12. Prozialeck WC, Edwards JR (2010) Early biomarkers of cadmium exposure and nephrotoxicity. Biometals 23: 793-809.

13. Berglund M, Akesson A, Bjellerup P, Vahter M (2000) Metal-bone interactions. Toxicol Lett 112-113: 219-225.

14. Kazantzis G (2004) Cadmium, osteoporosis and calcium metabolism Biometals 17: 493-498.

15. Walter T, Olivares M, Pizarro F, Muñoz C (1997) Iron, anemia, and infection. Nutr Rev 55: 111-124.

16. Wang X, Zhou B (2010) Dietary zinc absorption: A play of Zips and ZnTs in the gut. IUBMB Life 62: 176-182.

17. Liuzzi JP, Cousins RJ (2004) Mammalian zinc transporters. Annu Rev Nutr 24: 151-172.

18. Matović V, Buha A, Bulat Z, Dukić-Ćosić D (2011) Cadmium toxicity revisited: Focus on oxidative stress induction and interactions with zinc and magnesium. Arh Hig Rada Toksikol 62: 65-76.

19. Enger MD, Hildebrand CE, Stewart CC (1983) Cd2+ responses of cultured human blood cells. Toxicol Appl Pharmacol 69: 214-224.

20. Goering PL, Kuester RK, Neale AR, Chapekar MS, Zaremba TG, et al. (2000) Effects of particulate and soluble cadmium species on biochemical and functional parameters in cultured murine macrophages. In Vitr Mol Toxicol 13: 125-136.

21. Freitas M, Lima JLFC, Porta G, Fernandes E (2010) Metal-induced oxidative burst in isolated human neutrophils. Microchem J 96: 167-171.

22. Zhong ZJ, Troll W, Koenig KL, Frenkel K (1990) Carcinogenic sulphide salts of nickel and cadmium induce $\mathrm{H} 2 \mathrm{O} 2$ formation by human polymorphonuclear leucocytes. Cancer Res 50: 7564-7570.

23. Hassoun EA, Stohs SJ (1996) Cadmium-induced production of superoxide anion and nitric oxide, DNA single strand breaks and lactate dehydrogenase leakage in J774A.1 cell cultures. Toxicology 112: 219-226.

24. Ramirez DC, Martinez LD, Marchevsky E, Gimenez MS (1999) Biphasic effect of cadmium in non-cytotoxic conditions on the secretion of nitric oxide from peritoneal macrophages. Toxicology 139: 167-177.

25. Kim J, Sharma RP (2004) Calcium mediated activation of c-Jun NH2-termina kinase (JNK) and apoptosis in response to cadmium in murine macrophages. Toxicol Sci 81: 518-527.

26. Tintinger G, Steel HC, Anderson R (2005) Taming the neutrophil: calcium clearance and influx mechanisms as novel targets for pharmalogical control. Clin Exp Immunol 141: 191-200.

27. Hussain T, Shukla GS, Chandra SV (1987) Effects of cadmium on superoxide dismutase and lipid peroxidation in liver and kidney of growing rats: In vivo and in vitro studies. Pharmacol Toxicol 60: 355-358.

28. Matés JM, Segura JA, Alonso FJ, Márquez J (2010) Roles of dioxins and heavy metals in cancer and neurological diseases using ROS-mediated mechanisms. Free Radic Biol Med 49: 1328-1341.

29. Kudo N, Nakagawa Y, Waku K (1996) Biphasic effect of cadmium ions on the secretion of leukotriene B4 in rabbit alveolar macrophages. Arch Toxicol 70: 801-808.

30. Marth E, Barth S, Jelovcan S (2000) Influence of cadmium on the immune system. Description of stimulating reactions. Cent Eur J Public Health 8: 40-44.
31. Freitas $M$, Fernandes $E$ (2011) Zinc, cadmium and nickel increase the activation of NF-KB and the release of cytokines from THP-1 monocytic cells. Metallomics 3: $1238-1243$.

32. Patra RC, Rautray AK, Swarup D (2011) Oxidative Stress in Lead and Cadmium Toxicity and Its Amelioration. Vet Med Int 2011: 457327.

33. Kataranovski M, Kataranovski D, Savic D, Jovcic G, Bogdanovic Z, et al. (1998) Granulocyte and plasma cytokine activity in acute cadmium intoxication in rats. Physiol Res 47: 453-461.

34. Kirschvink N, Vincke G, Fiévez L, Onclinx C, Wirth D, et al. (2005) Repeated cadmium nebulizations induce pulmonary MMP-2 and MMP-9 production and emphysema in rats. Toxicology 211: 36-48.

35. Fukuda K, Hitsuda Y, Igishi T (1997) Cadmium induces interleukin 8 in alveolar epithelial type II cells (A549). Yonago Acta Med 40: 43-52.

36. Villanueva MBG, Koizumi S, Jonai H (2000) Cytokine production by human peripheral blood mononuclear cells after exposure to heavy metals. J Health Sci 46: 358-362

37. Bernhard D, Rossmann A, Henderson B, Kind M, Seubert A, et al. (2006) Increased serum cadmium and strontium levels in young smokers: effects on arterial endothelial cell gene transcription. Arterioscler Thromb Vasc Biol 26: 833-838.

38. Mannino DM, Holguin F, Greves HM, Savage-Brown A, Stock AL, et al. (2004) Urinary cadmium levels predict lower lung function in current and forme smokers: data from the Third National Health and Nutrition Examination Survey. Thorax 59: 194-198.

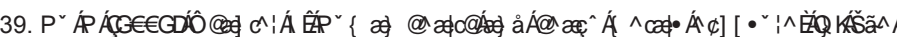

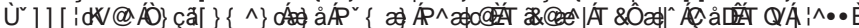

40. United Nations Environment Programme, Chemicals Branch, DTIE. Draft: Final Review of Scientific Information on Lead. Version of November 2008.

41. Zielhuis RL, del Castilho P, Herber RF, Wibowo AA (1978) Levels of lead and other metals in human blood: Suggestive relationships, determining factors. Environ Health Perspect 25: 103-109.

42. Richter PA, Bishop EE, Wang J, Swahn MH (2009) Tobacco smoke exposure and levels of urinary metals in the U.S. youth and adult population: The National Health and Nutrition Examination Survey (NHANES) 1999-2004. Int J Environ Res Public Health 6: 1930-1946.

43. Farooq Y, Hussain MM, Aleem SB, Farooq MA (2008) Lead intoxication: the extent of problem and its management. Pak J Physiol 4: 36-41.

44. Bergeret A, Pouget E, Tedone R, Meygret T, Cadot R, et al. (1990) Neutrophil functions in lead-exposed workers. Hum Exp Toxicol 9: 231-233.

45. Valentino M, Governa M, Marchiseppe I, Visonă I (1991) Effects of lead on polymorphonuclear leukocyte (PMN) functions in occupationally exposed workers. Arch Toxicol 65: 685-688.

46. Queiroz ML, Almeida M, Gallão MI, Höehr NF (1993) Defective neutrophil function in workers occupationally exposed to lead. Pharmacol Toxicol 72: 7377.

47. Queiroz ML, Costa FF, Bincoletto C, Perlingeiro RC, Dantas DC, et al. (1994) Engulfment and killing capabilities of neutrophils and phagocytic splenic function in persons occupationally exposed to lead. Int J Immunopharmacol 16: $239-244$

48. Undeğer U, Başaran N (1998) Effects of lead on neutrophil functions in occupationally exposed workers. Environ Toxicol Pharmacol 5: 113-117.

49. Di Lorenzo L, Silvestroni A, Martino MG, Gagliardi T, Corfiati M, et al. (2006) Evaluation of peripheral blood neutrophil leucocytes in lead-exposed workers. Int Arch Occup Environ Health 79: 491-498.

50. Van Eeden SF, Hogg JC (2000) The response of human bone marrow to chronic cigarette smoking. Eur Respir J 15: 915-921.

51. Kanematsu M, Takagi K, Masuda N, Suketa Y (1996) Lead inhibits nitric oxide production transiently by mRNA level in murine macrophage cell lines. Bio Pharm Bull 19: 949-951.

52. Mishra KP, Chauhan UK, Naik S (2006) Effect of lead exposure on serum immunoglobulins and reactive nitrogen and oxygen intermediate. Human Exp Toxicol 25: 661-665

53. Villanueva R, Albaladejo R, Ortega P, Astasio P, Calle ME, et al. (1997) Adherence of mouse peritoneal macrophages following exposure to lead. Ind Health 35: 291-293. 
Citation: Theron AJ, Tintinger GR, Anderson R (2012) Harmful Interactions of Non-Essential Heavy Metals with Cells of the Innate Immune System. J Clinic Toxicol S3:005. doi:10.4172/2161-0495.S3-005

54. Villanueva R, Albaladejo R, Ortega P, Astasio P, Gil A, et al. (1997) Chemotaxis of mouse peritoneal macrophages following exposure to lead. Bull Environ Contam Toxicol 59: 159-163.

55. Flohé SB, Brüggemann J, Herder C, Goebel C, Kolb H (2002) Enhanced proinflammatory response to endotoxin after priming of macrophages with lead ions. J Leukoc Biol 71: 417-424.

56. Valentino M, Rapisarda V, Santarelli L, Bracci M, Scorcelletti M, et al (2007) Effect of lead on the levels of some immunoregulatory cytokines in occupationally exposed workers. Hum Exp Toxicol 26: 551-556.

57. Dabrowska-Bouta B, Struzyńska L, Rafałowska U (1996) Effect of acute and chronic lead exposure on the level of sulfhydryl groups in rat brain. Acta Neurobiol Exp (Wars) 56: 233-236.

58. Costa LG, Guizzetti M, Lu H, Bordi F, Vitalone A, et al. (2001) Intracellula signal transduction pathways as targets for neurotoxicants. Toxicology 160 : 19-26.

59. Bose-O'Reilly S, McCarty KM, Steckling N, Lettmeier B (2010) Mercury exposure and children's health. Curr Probl Pediatr Adolesc Health Care 40: 186-215.

60. Agency for Toxic Substances and Disease Registry (ATSDR) (1999) Toxicological profile for mercury. Centers for Disease Control. Atlanta, Georgia TP-93/10.

61. Vas J, Monestier M (2008) Immunology of mercury. Ann N Y Acad Sci 1143 240-267

62. Soleo L, Vacca A, Vimercati L, Bruno S, Di Loreto M, et al. (1997) Minima immunological effects on workers with prolonged low exposure to inorganic mercury. Occup Environ Med 54: 437-442.

63. Gross MJ, Harrison IA (1989) Some electrochemical features of the in vivo corrosion of dental amalgams. J Appl Electrochem 19: 301-310.

64. Mercola J, Klinghardt D (2001) Mercury toxicity and systemic elimination agents. J Nutr \& Environ Med 11: 53-62.

65. Zahir F, Rizwi SJ, Haq SK, Khan RH (2005) Low dose mercury toxicity and human health. Environ Toxicol Pharmacol 20: 351-360.

66. Holmes P, James KA, Levy LS (2009) Is low-level environmental mercury exposure of concern to human health. Sci Total Environ 408: 171-182.

67. Via CS, Nguyen P, Niculescu F, Papadimitriou J, Hoover D, et al. (2003) Low-dose exposure to inorganic mercury accelerates disease and mortality in acquired murine lupus. Environ Health Perspect 111: 1273-1277.

68. Suzuki Y, Inoue T, Ra C (2011) Autoimmunity-inducing metals ( $\mathrm{Hg}, \mathrm{Au}$ and $\mathrm{Ag}$ ) modulate mast cell signaling, function and survival. Curr Pharm Des 17 3805-3814.

69. Jansson G, Harms-Ringdahl M (1993) Stimulating effects of mercuric- and silver ions on the superoxide anion production in human polymorphonuclear leukocytes. Free Radic Res Commun 18: 87-98.

70. Moisan E, Arbour S, Nguyen N, Hébert MJ, Girard D, et al. (2002) Prolongation of human neutrophil survival by low level mercury via inhibition of spontaneous apoptosis. J Toxicol Environ Health A 65: 183-203.

71. Perlingeiro RC, Queiroz ML (1995) Measurement of the respiratory burst and chemotaxis in polymorphonuclear leukocytes from mercury-exposed workers. Hum Exp Toxicol 14: 281-286.

72. Christensen MM, Ellermann-Eriksen S, Rungby J, Mogensen SC (1993) Comparison of the interaction of methyl mercury and mercuric chloride with murine macrophages. Arch Toxicol 67: 205-211.

73. InSug O, Datar S, Koch CJ, Shapiro IM, Shenker BJ (1997) Mercuric compounds inhibit human monocyte function by inducing apoptosis: evidence for formation of reactive oxygen species, development of mitochondrial membrane permeability transition and loss of reductive reserve. Toxicology 124: $211-224$.

74. Kudo N, Waku K (1994) Mercuric chloride induces the production of leukotriene B4 by rabbit alveolar macrophages. Arch Toxicol 68: 179-186.

75. Flamand N, Surette ME, Picard S, Bourgoin S, Borgeat P (2002) Cyclic AMP-mediated inhibition of 5-lipoxygenase translocation and leukotriene biosynthesis in human neutrophils. Mol Pharmacol 62: 250-256.

76. Kim SH, Johnson VJ, Sharma RP (2002) Mercury inhibits nitric oxide production but activates proinflammatory cytokine expression in murine macrophage differential modulation of NF-kappaB and p38 MAPK signaling pathways. Nitric Oxide 7: 67-74.

77. Gardner RM, Nyland JF, Evans SL, Wang SB, Doyle KM, et al. (2009) Mercury induces an unopposed inflammatory response in human peripheral blood mononuclear cells in vitro. Environ Health Perspect 117: 1932-1938.

78. Ilbäck NG (1991) Effects of methyl mercury exposure on spleen and blood natural killer (NK) cell activity in the mouse. Toxicology 67: 117-124.

79. Ilbäck NG, Sundberg J, Oskarsson A (1991) Methyl mercury exposure via placenta and milk impairs natural killer (NK) cell function in newborn rats. Toxicol Lett 58: 149-158.

80. Migdal C, Tailhardat M, Courtellemont P, Haftek M, Serres M (2010) Responsiveness of human monocyte-derived dendritic cells to thimerosal and mercury derivatives. Toxicol Appl Pharmacol 246: 66-73.

81. Migdal C, Foggia L, Tailhardat M, Courtellemont P, Haftek M, et al. (2010) Sensitization effect of thimerosal is mediated in vitro via reactive oxygen species and calcium signaling. Toxicology 274: 1-9.

82. Han SG, Castranova V, Vallyathan V (2007) Comparative cytotoxicity of cadmium and mercury in a human bronchial epithelial cell line (BEAS-2B) and its role in oxidative stress and induction of heat shock protein 70 . J Toxico Environ Health A 70: 852-860.

83. Stohs SJ, Bagchi D (1995) Oxidative mechanisms in the toxicity of metal ions Free Radic Biol Med 18: 321-336

84. Pierce LM, Alessandrini F, Godleski JJ, Paulauskis JD (1996) Vanadiuminduced chemokine mRNA expression and pulmonary Inflammation. Toxicol Appl Pharmacol 138: 1-11.

85. Cohen MD (2007) Toxicity of Vanadium Compounds: Pulmonary and Immune System Targets. In: ACS Symposium Series: Vanadium the Versatile Metal, Chapter 16, 974: 217-239

86. Adachi A, Asai K, Koyama Y, Matsumoto Y, 2 kano T (1998) Determination of vanadium in cigarettes by atomic absorption spectrophotometry. Analyt Lett 31: 1769-1776.

87. Fickl H, Theron AJ, Grimmer H, Oommen J, Ramafi GJ, et al. (2006) Vanadium promotes hydroxyl radical formation by activated human neutrophils. Free Radic Biol Med 40: 146-155.

88. Grabowski GM, Paulauskis JD, Godleski JJ (1999) Mediating Shosphorylation events in the vanadium-induced respiratory burst of alveolar macrophages. Toxicol Appl Pharmacol 156: 170-178.

89. Wang L, Medan D, Mercer R, Overmiller D, Leornard S, et al. (2003) Vanadiuminduced apoptosis and pulmonary inflammation in mice: Role of reactive oxygen species. J Cell Physiol 195: 99-107.

90. Chong IW, Lin SR, Hwang JJ, Huang MS, Wang TH, et al. (2000) Expression and regulation of macrophage inflammatory protein-2 by vanadium in mouse macrophages. Inflammation 24: 127-139.

91. Chong IW, Shi MM, Love JA, Christiana DC, Paulauskis JD (2000) Regulation of chemokine mRNA expression in a rat model of vanadium-induced pulmonary inflammation. Inflammation 24: 505-517.

92. Jaspers I, Samet JM, Reed W (1999) Arsenite exposure of cultured airway epithelial cells activates kB-dependent interleukin-8 gene expression in the absence of Nuclear Factor-kB nuclear translocation. J Biol Chem 274: 31025 31033.

93. Zhang Z, Huang C, Li J, Leonard SS, Lanciotti R, et al. (2001) Vanadateinduced cell growth regulation and the role of reactive oxygen species. Arch Biochem Biophys 392: 311-320.

94. Kitani S, Rajiva De Silva N, Morita Y, Teshima R (1998) Global environmental pollutant substance vanadium activates mast cells and basophils at the late phase in the presence of hydrogen peroxide. Environ Toxicol Pharmacol 6: $1-12$.

95. Chen F, Demers LM, Vallyathan V, Ding M, Lu Y, et al. (1999) Vanadate induction of NF-kappaB involves IkappaB kinase beta and SAPK/ERK kinase 1 in macrophages. J Biol Chem 274: 20307-20312.

96. Valko M, Morris H, Cronin MT (2005) Metals, toxicity and oxidative stress. Cur Med Chem 12: 1161-1208.

97. Ravindra K, Bencs L, Van Grieken R (2004) Platinum group elements in the environment and their health risk. Sci Total Environ 318: 1-43. 
Citation: Theron AJ, Tintinger GR, Anderson R (2012) Harmful Interactions of Non-Essential Heavy Metals with Cells of the Innate Immune System. J Clinic Toxicol S3:005. doi:10.4172/2161-0495.S3-005

98. Conti ME, Alimonti A, Bocca B (2008) Environmental exposure to platinum group elements released by automotive catalytic converters: the risk for children. Int J Environ Health 2: 439-462.

99. Theron AJ, Ramafi GJ, Feldman C, Grimmer H, Visser SS, et al. (2004) Effects of platinum and palladium ions on the production and reactivity of neutrophilderived reactive oxygen species. Free Radic Biol Med 36: 1408-1417.

100.Schmid M, Zimmermann S, Krug HF, Sures B (2007) Influence of platinum, palladium and rhodium as compared with cadmium, nickel and chromium on cell viability and oxidative stress in human bronchial epithelial cells. Environ Int 33: 385-390.

101.Schins RP, Polat D, Begerow J, Turfeld M, Becker A, et al. (2004) Platinum levels in nasal lavage fluid as biomarker for traffic-related exposure and inflammation in children. Sci Total Environ 334-335: 447-455.

102. Feldman C, Theron A, Anderson R (2005) Neutrophils potentiate platinummediated injury to human ciliated epithelium in vitro. Inhal Toxicol 17: 297-301.

103. Brunet L, Pai M, Davids V, Ling D, Paradis G, et al. (2011) High prevalence of smoking among patients with suspected tuberculosis in South Africa. Eur Respir J 38: 139-146.

104.Tachfouti N, Nejjari C, Benjelloun MC, Berraho M, Elfakir S, et al. (2011) Association between smoking status, other factors and tuberculosis treatment failure in Morocco. Int J Tuberc Lung Dis 15: 838-843.

105. Nuorti JP, Butler JC, Farley MM, Harrison LH, McGeer A, et al. (2000) Cigarette smoking and invasive pneumococcal disease. Active bacterial core surveillance team. N Engl J Med 342: 681-689.

106. Bagaitkar J, Demuth DR, Daep CA, Renaud DE, Pierce DL, et al. (2010) Tobacco upregulates $\mathrm{P}$. gingivalis fimbrial proteins which induce TLR2 hyposensitivity. PLoS One 5: e9323.

107.Goldstein-Daruech N, Cope EK, Zhao KQ, Vukovic K, Kofonow JM, et al. (2011) Tobacco smoke mediated induction of sinonasal microbial biofilms. PLoS One 6: e15700.

108.Deep A, Chaudhary U, Gupta V (2011) Quorum sensing and bacterial pathogenicity from molecules to disease. J Lab Physicians 3: 4-11.

109. Torjussen W, Zachariasen H, Andersen I (2003) Cigarette smoking and nickel exposure. J Environ Monit 5: 198-201.
110. Järup L (2003) Hazards of heavy metal contamination. Br Med Bull 68: 167182.

111. Nawrot TS, Staessen JA, Roels HA, Munters E, Cuypers A, et al. (2010) Cadmium exposure in the population: from health risks to strategies of prevention. Biometals 23: 769-782.

112. Perrin C, Briandet R, Jubelin G, Lejeune $P$, Mandrand-Berthelot MA, et al (2009) Nickel promotes biofilm formation by Escherichia coli K-12 strains that produce curli. Appl Environ Microbiol 75: 1723-1733.

113. Fickl H, Theron AJ, Anderson R, Mitchell TJ, Feldman C (2007) Palladium attenuates the pro-inflammatory interactions of $\mathrm{C} 5 \mathrm{a}$, interleukin-8 and pneumolysin with human neutrophils. J Immunotoxicol 4: 247-252.

114. Natelson EA, Blumenthal BJ, Fred HL (1971) Acute mercury vapour poisoning in the home. Chest 59: 677-678.

115. Leduc $D$, de Francquen $P$, Jacobovitz $D$, Vandeweyer $R$, Lauwerys $R$, et al (1993) Association of cadmium exposure with rapidly progressive emphysema in a smoker. Thorax 48: 570-571.

116. Krantz A, Dorevitch S (2004) Metal exposure and common chronic diseases: a guide for the clinician. Dis Mon 50: 220-262

117. Fuortes L, Leo A, Ellerbeck PG, Friell LA (1991) Acute respiratory fatality associated with exposure to sheet metal and cadmium fumes. J Toxicol Clin Toxicol 29: 279-283.

118. Seidal K, Jörgensen N, Elinder CG, Sjögren B, Vahter M (1993) Fatal cadmium-induced pneumonitis. Scand J Work Environ Health 19: 429-431.

119. Deschamps F, Strady C, Deslee G, Menciere-Faroy B, Deschamps S (2002) Five years follow-up after elemental mercury self-poisoning. Am J Forensic Med Pathol 23: 170-172.

120.Dell'Omo M, Muzi G, Bernard A, Filiberto S, Lauwerys RR, et al. (1997) Longterm pulmonary and systemic toxicity following intravenous mercury injection. Arch Toxicol 72: 59-62.

121. Stayner L, Smith R, Thun M, Schnorr T, Lemen R (1992) A dose-response analysis and quantitative assessment of lung cancer risk and occupational cadmium exposure. Ann Epidemiol 2: 177-194.

122. Järup L, Pershagen G (1991) Arsenic exposure, smoking, and lung cancer in smelter workers -- a case-control study. Am J Epidemiol 134: 545-551.
This article was originally published in a special issue, Heavy Metal Toxicity handled by Editor(s). Dr. Noreen Khan-Mayberry, National Aeronautics \& Space Administration at Lyndon B. Johnson Space Center in Houston, USA
Submit your next manuscript and get advantages of OMICS Group submissions

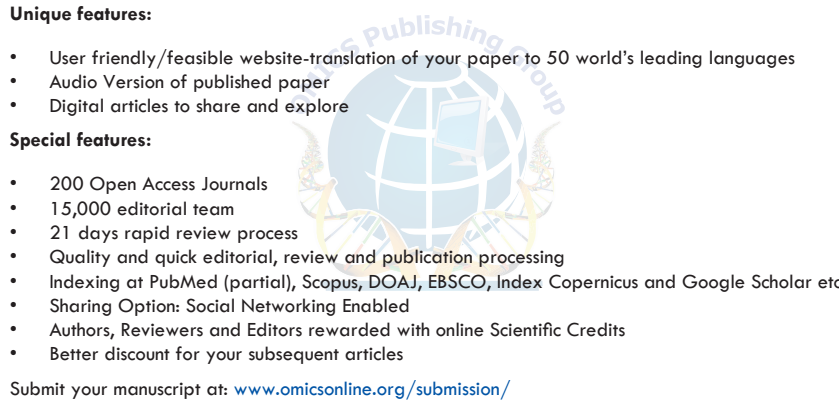

Submit your manuscript at: www.omicsonline.org/submission/ 